\title{
Functional Ice Cream with Coffee-Related Flavor
}

\author{
Manal Khider*, Neveen Ahmed, Wedad Azab Metry \\ Dairy Department, Faculty of Agriculture, Fayoum University, Fayoum, Egypt \\ Email: *mqa00@fayoum.edu.eg
}

How to cite this paper: Khider, M., Ahmed, N. and Metry, W.A. (2021) Functional Ice Cream with Coffee-Related Flavor. Food and Nutrition Sciences, 12, 826-847. https://doi.org/10.4236/fns.2021.128062

Received: May 9, 2021

Accepted: August 24, 2021

Published: August 27, 2021

Copyright $\odot 2021$ by author(s) and Scientific Research Publishing Inc. This work is licensed under the Creative Commons Attribution International License (CC BY 4.0).

http://creativecommons.org/licenses/by/4.0/

\begin{abstract}
In this study, Siwi roasted date seeds (pits) as a by-product of the date factories were used in powder form for ice cream fortification to produce a new product with coffee-like flavor. Also, this product possesses functional, nutritional and health benefits as it contains, minerals, phenolic compounds and possess antioxidant activity. Six ice cream mixes were prepared: plain ice cream without additives (control), five ice cream treatments supplemented with powder of the Nescafé (3\%), Coffee (3\%) and Roasted Date Seeds Powder (RDSP) with ratio of $3 \%, 4 \%$ and $5 \%$, respectively. The results showed that increasing the added percentage of Roasted Date Seeds Powder (RDSP) to the ice cream mixes leads to an increase in the total solids, fibers, total nitrogen and ash content of the final product. It also increases viscosity, specific gravity, weight per gallon and increase the depression of freezing point of the mixes. The overrun and melting resistance of the final ice cream also increased compared with the control. The sensory evaluation was improved by adding RDSP comparing to control. So in this study, it is recommended to use RDSP as the source of minerals and health-promoting for ice cream making, as it contains bioactive compounds and also gives the ice cream desirable color and coffee-like flavor, but free of caffeine.
\end{abstract}

\section{Keywords}

Antioxidant Activity, Functional Ice Cream, By Product, Nutritional and Health Benefits, Phenolic Compounds, Roasted Date Seeds Powder

\section{Introduction}

Ice cream and ice milk are delicious, healthy, nutritious, favorite and popular frozen dessert for millions of people, because it's sweet, creamer, flavorful and pleasing to the palate and the eyes. Many kinds of ice milk formulations exist in the 
market, but new formulations are also required to enlarge the market proportion [1]. Consumers see naturalism as an important property and natural foods are considered to be safer and even healthier than artificial food [2]. So a healthy lifestyle through the diet is one of the consumers' demands and interests to reduce the risk of disease and to maintain their state of health [3]. Coffee is the favorite for some consumers, its consumption has greatly increased all around the world since the opening of the first coffee house in Mecca at the end of the fifteenth century. In 2010, coffee production reached 8.1 million tons worldwide according to International Coffee Organization (ICO, 2011) [4]. Another type of coffee is Nescafé, it is $100 \%$ pure coffee, made from a blend of coffee beans, which are carefully roasted to capture its full flavor and aroma and it has a unique taste.

Coffee is the main source of caffeine, also it contains many different nutritious and phenolic compounds [5]. Moreover, it contains caffeine which through multiple molecular mechanisms is mainly responsible for the antidepressant effects of coffee [6]. However, consumption of heavy coffee may be related to some undesirable symptoms, mainly headache, anxiety, increased blood pressure, nausea, and restlessness [7]. Therefore, several attempts are made to find cheap natural alternatives to the flavor of coffee to reduce its negative effect.

Date palm seeds are a waste product of many date fruit processing plants. It can be a source of dietary fiber without any negative impact on human health or the sensory quality of end-product if seeds are properly milled [8] [9]. The seeds presented about $6 \%-15 \%$ of the total weight of the mature date, depending on variety and grade quality [10]. Date pits contain different compounds such as minerals, crude fiber, total phenols, carbohydrates, saturated and unsaturated fatty acids [11]. The date by-products are safe for humans to be consumed and because it contains high-value components it is possible to be used in some applications, like using in making functional foods and as ingredients in nutraceutical, pharmaceuticals and medicine [12]. Also, this by-product could be a valuable and excellent source for low-priced functional food components [13]. Thus, one of its applications is using them as a dietary-fiber provider in bakery formulations. Another function includes roasting the date pits and making a drink free of caffeine which can substitute coffee when caffeine is a concern but a coffee-related flavor is desired, such a drink is used by the Arabs for a long time. A commercial product (date pits powder-coffee substitute) has also been introduced recently to the market, this is available in two types: plain and blended with coffee [14].

According to the above-mentioned knowledge this study aimed to make a novel healthy functional ice cream with coffee related flavor using Roasted Date Seeds Powder (RDSP) by product as an additive reach in phenolic compounds and has given nutritional benefits, antioxidant activity and adorable color, comparing with that made using coffee and Nescafé and investigating using each separately for making the functional ice cream and study their effect on its chemical, physical and organoleptic properties. 


\section{Materials and Methods}

\subsection{Materials}

Fresh raw buffalo's milk was obtained from Assaf farm, Fayoum, Egypt. Low heat skim milk powder (3\% moisture, imported from European Economic Community, Holland) was obtained from Dairy Processing Pilot Plant, Fac. Agric., Fayoum Univ., Fayoum, Egypt. Siwi date (Phoenix dactylifera L.), Coffee powder, Nescafé powder, vanilla and sugar were purchased from local market. All chemicals and reagents that used for this study were of analytical grades and were obtained from Sigma and Merck Companies.

\subsection{Methods}

\section{Preparation of Roasted Date Seeds Powder (RDSP)}

The seeds of Siwi date (Phoenix dactylifera L.) were prepared according to Al-Degs et al. (2013) [15], with some modification of the roasting degree. The seeds were separated from the pulp, washed to remove any remaining date flesh and boiled at $100^{\circ} \mathrm{C} \pm 1^{\circ} \mathrm{C}$ for $30 \mathrm{~min}$, then washed thoroughly with water and air dried for about $14 \mathrm{~h}$. After that the seeds were roasted in the oven at $200^{\circ} \mathrm{C} \pm$ $6^{\circ} \mathrm{C}$ for $12-15 \mathrm{~min}$. The date seeds were broken with hummer and milled in grinder and then sieved (100 mesh) to obtain the powder, which sealed in bags and stored at $4^{\circ} \mathrm{C} \pm 2^{\circ} \mathrm{C}$ until used.

Determination of phenolic compounds and antioxidant activity of the added raw materials

The total phenolic compounds and antioxidant activity were determined in the raw materials according to Shin et al. (2007) [16] and Pacôme et al. (2014) [17], respectively. The samples of all previous raw materials were extracted separately with methanol/water $(80 / 20 \mathrm{~V} / \mathrm{V})$ at $5^{\circ} \mathrm{C}$ for overnight and then filtrated through Whatman No. 1. The extract of each sample was kept under cooling till use in the determination of both phenolic content and antioxidant activity. The content of total phenolic compounds was determined using Folin Ciocalteu colorimetric method and calculated as a percentage of each sample according to Shin et al. (2007) [16]. Amount of each sample extract separately transferred into a test tube; $50 \mu \mathrm{l}$ of RDSP extract, $50 \mu \mathrm{l}$ of diluted Nescafé extract $(1 \mathrm{ml}$ extract + $1 \mathrm{ml}$ methanol), $50 \mu \mathrm{l}$ of diluted coffee extract ( $1 \mathrm{ml}$ extract $+3 \mathrm{ml}$ methanol). Then $50 \mu \mathrm{l}$ of Folin-Ciocalteu reagent and $\sim 1950 \mu \mathrm{l}$ of distilled water were transferred into each previous test tube. All tubes were shaken and allowed to stand at room temperature for $6 \mathrm{~min}$. in a dark place. Then $1.5 \mathrm{ml}$ of $\mathrm{Na}_{2} \mathrm{CO}_{3}(20 \%)$ was added and stand for two hours in the dark. The absorbance was measured at 765 nm using Chrome Tech model: CT-2400 UV/V is spectrophotometer against methanol blank. The total phenolic content was calculated from a standard curve prepared by using Gallic acid solution $[0.1013 \mathrm{~g} / 100 \mathrm{ml}$ mixture of methanol and water $(80 / 20 \mathrm{~V} / \mathrm{V})]$. Serial concentrations $(10-60 \mu \mathrm{g} / \mathrm{ml})$ of Gallic acid solution were prepared for measuring the standard curve. The calibration equation for 
Gallic acid was $Y=0.0334 X+0.1472 ; \mathrm{R}^{2}=0.993$, where, $\mathrm{y}$ is the absorbance and $x$ is concentration of Gallic acid in $\mu \mathrm{g} / \mathrm{mL}$. The mean at least of three readings was calculated and expressed as mg of Gallic acid equivalents (mg GAE)/100 $\mathrm{g}$ of the sample.

\section{Determination of radical scavenging activity}

The free radical scavenging activity for the raw materials was determined by using the 1,1-dipheny-2-picryl-hydrazyl (DPPH) assay according to Pacôme et al. (2014) [17]. In this method, $0.1 \mathrm{mM}$ of DPPH solution in methanol was prepared (6 mg DPPH/100 ml methanol), and $1.8 \mathrm{ml}$ of this solution was added to different concentrations of the sample extract (methanol/water 80/20 V/V). The mixture was left to stand at room temperature for $30 \mathrm{~min}$. in the dark before measuring the absorbance at $517 \mathrm{~nm}$ to assess the stability of the colored reactive action. The methanol was used as blank, while the control sample was prepared to contain the same volume of DPPH without any extract.

\section{Experimental procedure}

Six ice cream mixes were prepared according to the method described by Marshall et al. (2003) [18]. All the ice cream mixes made with adding; sugar, skim milk powder, CMC stabilizer and vanilla with concentrations of 15, 3, 0.4 and $0.01 \%$, respectively. Preparation of basic ice cream mixes were done according to the Egyptian Standards of ice cream (2005) [19]. Preliminary experiments were carried out using levels of $1 \%, 2 \%, 3 \%, 4 \%$ and $5 \%$ to select the best ratios of each coffee, Nescafé and RDSP. The main processing steps for all ice cream treatments are shown in Figure 1, and formulated as follows:

C: Plain ice cream without additives (Control);

$\mathrm{T}_{1}$ : Ice cream supplemented with $3 \%$ Nescafé powder;

$\mathrm{T}_{2}$ : Ice cream supplemented with $3 \%$ coffee powder;

$\mathrm{T}_{3}, \mathrm{~T}_{4}$ and $\mathrm{T}_{5}$ : Ice cream supplemented with $3 \%, 4 \%$ and $5 \%$ RDSP, respectively.

\section{Analytical methods}

All samples of the different ice cream mixes were evaluated for their physical and chemical properties as well as the sensory quality attributes. The samples of each treatment were analyzed in three replicates for each parameter.

\section{Physical properties}

The physical properties of the ice cream mixes were measured after aging, while, the resultant frozen ice cream was measured after $24 \mathrm{~h}$ of freezing.

\section{Viscosity, first drop, melting resistance and overrun}

The viscosity expressed as centipoises (CP) for the homogenized samples of ice cream mixes were carried out as described by Toledo (1980) [20]. Melting resistance was determined as mentioned by Moeenfard and Tehrani (2008) [21], with some modification. A block of each frozen ice cream samples (30 g) were placed on a wire mesh screen $(1.5 \mathrm{~mm} \times 1.5 \mathrm{~mm})$ which located on top of a beaker at room temperature $\left(25^{\circ} \mathrm{C} \pm 2{ }^{\circ} \mathrm{C}\right)$ to determine the first drop time and melting resistance. The time ( $\mathrm{min}$ ) elapsed to obtain the first drop was registered as a standup time. 
$12 \mathrm{Kg}$ fresh buffalo's milk ( $8 \%$ fat and $0.17 \%$ T.A)

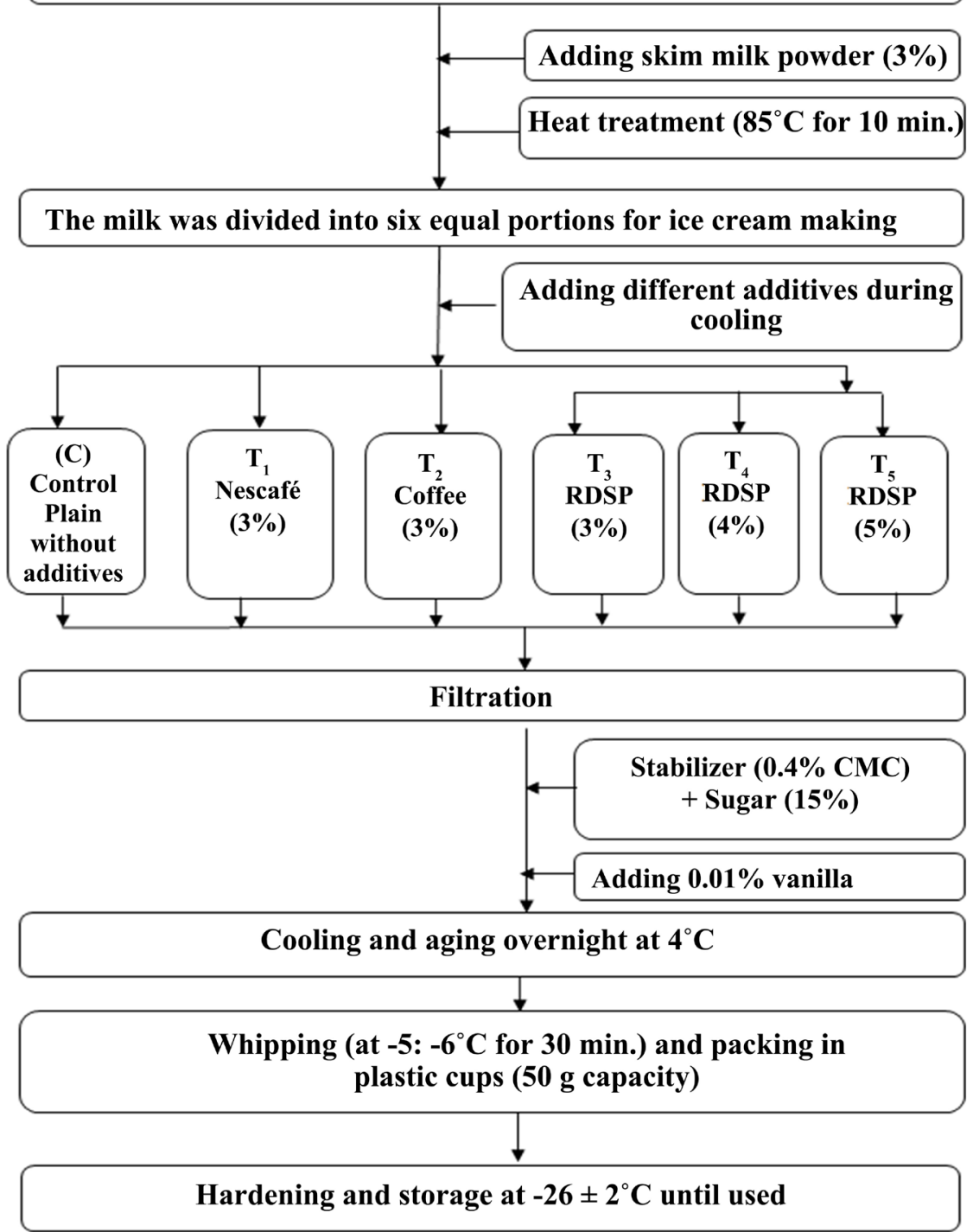

Figure 1. Flow diagram showing steps under taken for manufacturing the different functional ice cream treatments with coffee related flavor.

\section{Specific gravity, weight per gallon and freezing point}

The specific gravity was determined as mentioned by Winton (1958) [22]; filling a cool cup (with known weight and volume), with the resultant ice cream sample then weighted. Then the weight per gallon of the ice cream mixes and the final frozen products were calculated (Kg) according to Arbuckle (1986) [23] by multiplying the specific gravity by the factor 3.345. Freezing point of the ice cream mixes were measured as described by FAO (1977) [24].

[Specific gravity $\left(\mathrm{g} / \mathrm{cm}^{3}\right)=$ Weight of ice cream/Cup volume]

\section{Color measurements}

The different ice cream samples were analyzed for colors by using a Chroma Meter; CR-400 optical sensor (Konica Minolta Sensing, Inc., Osaka, Japan) ac- 
cording to Park et al. (2015) [25]. The colorimeter was calibrated with a white standard plate $\left(\mathrm{L}^{\star}=97.83, \mathrm{a}^{\star}=0.43, \mathrm{~b}^{\star}=1.98\right)$.

\section{Chemical analyses}

The total solids, total nitrogen, ash and fat contents of the raw materials and different ice cream samples were determined using oven drying method, Kjeldahl method, incineration at $550^{\circ} \mathrm{C}$ and Gerber method, respectively as described in AOAC (2012) [26]. The $\mathrm{pH}$ values of the raw materials, ice cream samples were tested by laboratory $\mathrm{pH}$ meter with a glass electrode Model $\mathrm{pH}$-Thermo Scientific Orion Star (A214); each sample was mixed thoroughly and the $\mathrm{pH}$ was recorded.

\section{Minerals and crude fiber}

Minerals (Fe, $\mathrm{P}, \mathrm{K}, \mathrm{Ca}, \mathrm{Mg}, \mathrm{Zn}, \mathrm{Ni}, \mathrm{Mn}, \mathrm{Cu}, \mathrm{Cd}$ and $\mathrm{Pb}$ ), were determined using Inductively Coupled Plasma (ICP) equipment (Model 6300 Duo UK, England); according to APHA (2005) [27]. The crude fiber content for ice cream samples was assessed by a sequential acid and alkali hydrolysis for the samples according to Rashida and Joy (2014) [28].

\section{Sensory evaluation}

The ice cream samples were sensory evaluated by regulars' test panels of 10 staff members from Dairy Depart., Fac. Agric., Fayoum Univ. The samples were evaluated according to Magdoub et al. (1989) [29] using a scheme of 10 points for color \& appearance, 10 points for melting quality, 30 points for body \& texture and 50 points for flavor.

\section{Statistical analysis}

All results were analyzed using General Linear Models (GLM) procedure of statistical package for social sciences [30], Version 17.0.0 software. Duncan (1955) [31] multiplied range tests were used to compare between the means.

\section{Results and Discussion}

\subsection{Gross Chemical Composition of the Raw Materials}

Chemical compositions of the used raw materials were illustrated in Table 1. The Total Solids (TS), Total Nitrogen (TN), ash, fat and fiber contents of the used milk were $13.73 \%, 0.62 \%, 0.76 \%, 8 \%$ and $0.00 \%$, respectively, while the $\mathrm{pH}$ value

Table 1. Gross chemical composition and $\mathrm{pH}$ values of the raw materials.

\begin{tabular}{ccccc}
\hline \multirow{2}{*}{ Parameters } & \multicolumn{3}{c}{ Raw materials } \\
\cline { 2 - 4 } & Milk & Coffee & Nescafé & RDSP \\
\hline Total solids (TS \%) & 13.73 & 98.5 & 98.60 & 98.20 \\
Total nitrogen (TN \%) & 0.62 & 3.5 & 3.64 & 1.67 \\
Ash (\%) & 0.76 & 4.5 & 6.52 & 1.76 \\
Fat (\%) & 8.00 & ND & ND & ND \\
Fiber (\%) & 0.00 & 61.9 & 56.70 & 41.90 \\
pH & 6.6 & 5.2 & 5.6 & 3.9 \\
\hline
\end{tabular}

ND: not determined, RDSP: roasted date seed powder. 
was 6.6. On the other hand, the gross chemical composition of Coffee was $98.5 \%$, $3.5 \%, 4.5 \%$ and $61.9 \%$ for TS, TN, ash and fiber contents, respectively, while, the $\mathrm{pH}$ value was 5.2 .

Regarding Nescafé, it contains about 3.64\% TN, 56.7\% fiber, $6.52 \%$ ash, and it has $\mathrm{pH}$ value of 5.6. Similar results were found by Oestreich-Janzen (2010) [32] and Farah (2012) [33]. In addition, the chemical composition of RDSP was $98.2 \%$ TS, $1.67 \% \mathrm{TN}, 41.9 \%$ fiber, $1.76 \%$ ash and $\mathrm{pH} 3.9$. These results are in accordance with Yousuf and Winterburn (2016) [34].

\subsection{Minerals Content of the Raw Materials}

Minerals content in different raw materials used in experimental ice cream making are shown in Table 2. In general, the minerals content of the raw materials statistically showed significant differences $(\mathrm{P} \leq 0.001)$. The highest elements in milk sample are calcium $(1124.3 \mathrm{mg} / \mathrm{Kg})$ and phosphorus $(1051.89 \mathrm{mg} / \mathrm{Kg})$, while the least one is nickel $(0.089 \mathrm{mg} / \mathrm{Kg})$. These results are close to what reported by Han et al. (2012) [35], Abd El-Salam and El-Shibiny (2011) [36]. The highest element content in RDSP was potassium, while the lowest element was cadmium. Samples of RDSP were higher in $\mathrm{Zn}$ content $(18.39 \mathrm{mg} / \mathrm{Kg})$ than the other samples. These results are close to what reported by Shi et al. (2014) [37]. Moreover, content of Nescafé sample from $\mathrm{Pb}, \mathrm{Cd}, \mathrm{Mg}, \mathrm{Ni}$ and $\mathrm{Cu}$ were 3.95, $0.419,2776.40,8.897$ and $66.61 \mathrm{mg} / \mathrm{Kg}$, respectively and this was higher than in the other samples. The contents of Coffee from minerals; K, Ca, P, Mn and Fe were $22,249.43,2495.83,3309.54,28.64$ and $98.12 \mathrm{mg} / \mathrm{Kg}$, respectively and this were higher than all other samples. The mineral results of Coffee are close to what obtain by Janda et al. (2020) [38] except iron and calcium were high in this study.

Table 2. Minerals content in the different raw materials.

\begin{tabular}{|c|c|c|c|c|c|}
\hline \multirow{2}{*}{$\begin{array}{l}\text { Elements } \\
(\mathrm{mg} / \mathrm{Kg})\end{array}$} & \multicolumn{5}{|c|}{ Raw materials } \\
\hline & Milk & RDSP & Nescafé & Coffee & $\mathrm{SE} \pm$ \\
\hline Phosphorus (P) & $1051.89^{\mathrm{D}}$ & $1355.93^{\mathrm{C}}$ & $3204.51^{\mathrm{B}}$ & $3309.54^{\mathrm{A}}$ & 0.972 \\
\hline Potassium (K) & $609.806^{\mathrm{D}}$ & $1702.33^{\mathrm{C}}$ & $16,790.297^{\mathrm{B}}$ & $22,249.43^{\mathrm{A}}$ & 54.200 \\
\hline Magnesium (Mg) & $113.620^{\mathrm{D}}$ & $788.51^{\mathrm{C}}$ & $2776.400^{\mathrm{B}}$ & $2477.360^{\mathrm{A}}$ & 5.478 \\
\hline Calcium (Ca) & $1124.30^{\mathrm{C}}$ & $312.26^{\mathrm{D}}$ & $1535.930^{\mathrm{B}}$ & $2495.830^{\mathrm{A}}$ & 77.160 \\
\hline Iron $(\mathrm{Fe})$ & $3.216^{\mathrm{D}}$ & $30.46^{\mathrm{C}}$ & $93.460^{\mathrm{B}}$ & $98.120^{\mathrm{A}}$ & 0.973 \\
\hline Zinc (Zn) & $6.099^{\mathrm{D}}$ & $18.37^{\mathrm{A}}$ & $6.850^{\mathrm{C}}$ & $11.152^{\mathrm{B}}$ & 0.228 \\
\hline Manganese (Mn) & $0.241^{\mathrm{D}}$ & $17.89^{\mathrm{C}}$ & $18.590^{\mathrm{B}}$ & $28.640^{\mathrm{A}}$ & 0.038 \\
\hline Copper $(\mathrm{Cu})$ & $1.410^{\mathrm{D}}$ & $8.66^{\mathrm{C}}$ & $66.610^{A}$ & $24.580^{\text {B }}$ & 0.433 \\
\hline Nickel (Ni) & $0.089^{\mathrm{D}}$ & $0.83^{\mathrm{C}}$ & $8.897^{\mathrm{A}}$ & $3.487^{\mathrm{B}}$ & 0.099 \\
\hline Cadmium (Cd) & $0.223^{\mathrm{C}}$ & $0.054^{\mathrm{D}}$ & $0.419^{\mathrm{A}}$ & $0.346^{\mathrm{B}}$ & 0.020 \\
\hline Lead (Pb) & $0.27^{\mathrm{C}}$ & $0.45^{\mathrm{B}}$ & $3.95^{\mathrm{A}}$ & $0.36^{\mathrm{BC}}$ & 0.495 \\
\hline
\end{tabular}

$\mathrm{A}, \mathrm{B}, \mathrm{C}$ and $\mathrm{D}$ : Means in the same row with different superscript letters are significantly different $(\mathrm{P} \leq$ 0.001). SE \pm : standard error, RDSP: roasted date seed powder. 


\subsection{Phenolic Compounds of the Raw Materials}

The extract of the phenolic compounds from Nescafé, Coffee and roasted date seeds powder was obtained by using mixture of methanol and water $(80 / 20 \mathrm{v} / \mathrm{v}$ ) (Albahari et al., 2018) [39].

The extract yield (Table 3) was varied from 7.6 to $49.8 \mathrm{~g} / 100 \mathrm{~g}$ dry weight (DW). The highest yield was noticed in the methanol and water (80/20) with Coffee sample (49.8 g/100g DW) followed by Nescafé (15.0 g/100g DW), while the RDSP recorded the lowest yield of phenolic extract $(7.6 \mathrm{~g} / 100 \mathrm{~g} D W)$. These results indicated that Coffee had the highest total phenolic content expressed as mg of gallic acid equivalents (GAE) (2940.829 mgGAE/100g) followed by Nescafé (1940.407 mg GAE/100g) and finally RDSP (587.782 mg GAE/100g). The content of RDSP from phenols is very close to what reported by Besbes et al. (2004a) [40]. In Table 3 the concentration required to inhibit 50\% of radical-scavenging effect $\left(E_{50}\right)$ was determined from the results of a series concentrations. A lower $\mathrm{EC}_{50}$ value corresponds to a larger scavenging activity. The $\mathrm{EC}_{50}$ values of RDSP was $21.9 \mu \mathrm{g} / \mu \mathrm{g}$ DPPH while that of Nescafé, was $16.0 \mu \mathrm{g} / \mu \mathrm{g}$ DPPH, but the $\mathrm{EC}_{50}$ value of the coffee sample was the highest $(79.0 \mu \mathrm{g} / \mu \mathrm{g}$ DPPH) and the antiradical efficiency were $0.046,0.063$ and 0.013 , respectively.

The antioxidant activity of different extracts from RDSP, coffee and Nescafé were determined using a methanol solution of DPPH reagent. DPPH has the advantage of being unaffected by certain side reactions, such as metal ion chelation and enzyme inhibition [41]. The effect of different samples extracts concentration on inhibition and remaining ratios are represented in Table 4, the free radical scavenging activity of RDSP, Nescafé and coffee extracts were evaluated at different concentrations against the stable free radical DPPH. It was noticed that the remaining percentage of DPPH is decreases as the concentration of sample extracts were increased. The percentage of remain ratio of DPPH and the inhibition ratio is depending on the type and amount of used sample. At low concentration of RDSP extract $(2.85 \mu \mathrm{g} / \mu \mathrm{g} \mathrm{DPPH})$, the remaining DPPH was $96.32 \%$ and the inhibition ratio was $3.68 \%$, while, it reached to $17.87 \%$ and $82.13 \%$, respectively when the concentration of RDSP increased to $76.00 \mu \mathrm{g} / \mu \mathrm{g}$ DPPH. Also both Nescafé and coffee extracts show similar trends but both were had high inhibition ratio which indicate high antioxidant activity; these results were in accordance with Janda et al. (2020) [38].

Table 3. Yield, total phenolic content, $\mathrm{EC}_{50}$ and antiradical efficiency of roasted date seeds, Nescafé and Coffee powders.

\begin{tabular}{ccccc}
\hline Raw materials & $\begin{array}{c}\text { Yield } \\
(\%)\end{array}$ & $\begin{array}{c}\text { Total phenolic content } \\
(\mathrm{mg} \text { GAE/100g sample) }\end{array}$ & $\begin{array}{c}\mathrm{EC}_{50} \\
(\mu \mathrm{g} / \mu \mathrm{g} \text { DPPH })\end{array}$ & $\begin{array}{c}\text { Antiradical } \\
\text { efficiencies }\end{array}$ \\
\hline RDSP & 7.6 & 587.782 & 21.9 & 0.046 \\
Nescafé & 15 & 1940.407 & 16.0 & 0.063 \\
Coffee & 49.8 & 2940.829 & 79.0 & 0.013 \\
\hline
\end{tabular}

EC: efficiency concentration, GAE: gallic acid equivalents, DPPH: 1,1-diphenyl-2-picryl hydrazyl, RDSP: Roasted date seeds powder. 
Table 4. Effect of different phenolic methanol extracts for the different raw materials on the inhibition ratio and remaining ratio of DPPH.

\begin{tabular}{|c|c|c|c|}
\hline $\begin{array}{l}\text { Raw materials } \\
\text { extracts }\end{array}$ & $\begin{array}{c}\text { Concentration of phenolic } \\
\text { extract }(\mu \mathrm{g} / \mu \mathrm{g} D P P H)\end{array}$ & $\begin{array}{l}\text { Inhibition } \\
\quad(\%)\end{array}$ & Remaining (\%) \\
\hline \multirow[t]{7}{*}{ RDSP } & 2.85 & 3.68 & 96.32 \\
\hline & 6.65 & 19.70 & 80.30 \\
\hline & 10.45 & 35.25 & 64.75 \\
\hline & 14.25 & 41.57 & 58.44 \\
\hline & 19.00 & 44.60 & 55.41 \\
\hline & 28.50 & 79.34 & 20.66 \\
\hline & 76.00 & 82.13 & 17.87 \\
\hline \multirow[t]{7}{*}{ Nescafé } & 5.44 & 31.20 & 68.80 \\
\hline & 12.68 & 42.88 & 57.12 \\
\hline & 19.93 & 55.90 & 44.11 \\
\hline & 27.18 & 57.96 & 35.00 \\
\hline & 36.24 & 84.34 & 15.66 \\
\hline & 54.36 & 89.30 & 10.74 \\
\hline & 72.48 & 88.36 & 11.64 \\
\hline \multirow[t]{7}{*}{ Coffee } & 18.68 & 22.62 & 77.38 \\
\hline & 43.58 & 28.20 & 71.82 \\
\hline & 68.475 & 43.30 & 56.74 \\
\hline & 93.375 & 53.06 & 46.94 \\
\hline & 124.50 & 76.48 & 23.52 \\
\hline & 186.75 & 82.62 & 17.38 \\
\hline & 249 & 85.57 & 14.43 \\
\hline
\end{tabular}

DPPH: 1,1-diphenyl-2-picryl hydrazyl, RDSP: roasted date seed powder.

\subsection{Gross Chemical Composition of Different Functional Ice Cream Treatments with Natural Coffee-Related Flavor}

The results in Table 5 explain the differences in TS contents between functional ice cream treatments and control. The differences between average total solids content of functional ice cream samples were highly significance $(P \leq 0.001)$. Where, the control sample had lower value (29.81\%) than all other treatments. The results indicate that, increasing the dietary fibers and ash content of the additives (Nescafé, Coffee and RDSP) caused an increase in the content of the TS in the resultant ice cream samples. These results are in agreement with those reported by Abdullah et al. (2003) [42].

Ayar et al. (2018) [43], also reported that an increase in dietary fiber quantity caused an increase in total solids content of the ice cream. Nescafé and Coffee ice cream samples have values of $32.14 \%$ and $32.07 \%$ TS, respectively. While, comparing to control sample, the addition of RDSP in the rate of $3 \%, 4 \%$ and $5 \%$ leads 
Table 5. Chemical composition and $\mathrm{pH}$ values of functional ice cream treatments with Coffee-related flavor.

\begin{tabular}{ccccccc}
\hline \multirow{2}{*}{ Treatments } & \multicolumn{5}{c}{ Parameters } \\
\cline { 2 - 7 } & TS (\%) & Fat (\%) & TN (\%) & Ash (\%) & Soluble fibers (\%) & pH \\
\hline $\mathrm{C}$ & $29.81^{\mathrm{E}}$ & $7.09^{\mathrm{C}}$ & $0.41^{\mathrm{D}}$ & $0.71^{\mathrm{E}}$ & $0.00^{\mathrm{E}}$ & $6.50^{\mathrm{A}}$ \\
$\mathrm{T}_{1}$ & $32.14^{\mathrm{A}}$ & $6.40^{\mathrm{D}}$ & $0.50^{\mathrm{BC}}$ & $0.97^{\mathrm{F}}$ & $1.70^{\mathrm{C}}$ & $6.15^{\mathrm{E}}$ \\
$\mathrm{T}_{2}$ & $32.07^{\mathrm{B}}$ & $6.17^{\mathrm{E}}$ & $0.49^{\mathrm{E}}$ & $0.95^{\mathrm{D}}$ & $1.86^{\mathrm{B}}$ & $6.35^{\mathrm{C}}$ \\
$\mathrm{T}_{3}$ & $29.91^{\mathrm{E}}$ & $7.76^{\mathrm{B}}$ & $0.43^{\mathrm{C}}$ & $0.79^{\mathrm{A}}$ & $1.26^{\mathrm{D}}$ & $6.45^{\mathrm{A}}$ \\
$\mathrm{T}_{4}$ & $31.34^{\mathrm{D}}$ & $7.76^{\mathrm{B}}$ & $0.45^{\mathrm{B}}$ & $0.80^{\mathrm{B}}$ & $1.70^{\mathrm{C}}$ & $6.40^{\mathrm{B}}$ \\
$\mathrm{T}_{5}$ & $31.59^{\mathrm{C}}$ & $7.98^{\mathrm{A}}$ & $0.49^{\mathrm{A}}$ & $0.83^{\mathrm{C}}$ & $2.10^{\mathrm{A}}$ & $6.25^{\mathrm{D}}$ \\
$\mathrm{SE} \pm$ & 0.004 & 0.001 & 0.002 & 0.001 & 0.003 & 0.014 \\
\hline
\end{tabular}

$\mathrm{A}, \mathrm{B}, \ldots$ and $\mathrm{F}$ : means in the same column with different superscript letters are significantly different $(\mathrm{P} \leq$ 0.001), SE \pm : standard error, TS: total solids, TN: total nitrogen, C: plain ice cream without additives (Control), $\mathrm{T}_{1}$ : ice cream made with $3 \%$ Nescafé, $\mathrm{T}_{2}$ : ice cream made with $3 \%$ Coffee; $\mathrm{T}_{3}, \mathrm{~T}_{4}$ and $\mathrm{T}_{5}$ : ice cream made with roasted date seed powder $3 \%, 4 \%$ and $5 \%$, respectively.

to an increase of the total solids to $29.91 \%, 31.343 \%$ and $31.59 \%$ respectively. This may due to the high content of TS\% in date seeds powder (see Table 1). These results are in agreement with those reported by Hashmi et al. (2011) [44]; El-Shobery et al. (2012) [45] and Younis (2012) [46].

Results mentioned in Table 5 also show that fat content of RDSP ice cream samples $\left(T_{3}, T_{4}\right.$ and $\left.T_{5}\right)$, were high as it gives values of $7.76 \%, 7.76 \%$ and $7.98 \%$, respectively. These results may due to the high fat content of RDSP; Besbes et al. (2004b) [47], studied the fat content of date seed and reported that it contains around $10.19 \%-12.67 \%$. On the other hand, both Nescafé and Coffee ice cream samples had the lowest values of fat content; $6.40 \%$ and $6.17 \%$, respectively. In addition, the fat content was increased with increasing the added level of RDSP; these results were disagreement with what reported by Younis (2012) [46]. Also results in Table 5 describe the difference in TN and ash contents of different ice cream treatments. The total nitrogen and ash content of the ice cream samples of all additives show a significant $(P \leq 0.001)$ difference. The highest TN content was found in $\mathrm{T}_{1}(0.50 \%)$, while the lowest one was noticed in control sample $(0.41 \%)$. Addition of RDSP leads to an increase of total nitrogen content, which was increasing with the added ratio $(3 \%, 4 \%$ and $5 \%)$; the readings were $0.43 \%$, $0.45 \%$ and $0.478 \%$, respectively. While, the results of TN for samples that contain either Nescafé or coffee were $0.50 \%$ and $0.49 \%$, respectively, these results were disagreement with finding of Younis (2012) [46].

\subsection{Ash Content of Ice Cream Treatments}

Ash content of the ice cream treatments made by RDSP (Table 5) recorded little increase with the proportional increasing ratios of the added RDSP in the mixes as the treatments $\mathrm{T}_{3} \mathrm{~T}_{4}$ and $\mathrm{T}_{5}$ are recorded; $0.79 \%, 0.80 \%$ and $0.83 \%$, respectively compared with control sample; $0.71 \%$. This may be attributed to the high 
minerals content in these treatments. These results are in agreement with Adeosun et al. (2016) [48]. On the other hand, the ash content in ice cream made by added Nescafé was higher $(0.97 \%)$ than that made by coffee $(0.95 \%)$ or date seeds powder and this is agreement with what reported by Oestreich-Janzen (2010) [32]; Yousuf and Winterburn (2016) [34].

The $\mathrm{pH}$ values (Table 5) of functional ice cream samples are a consequence of its ingredients; especially with regard to milk nitrogen, salts and dissolved gases. These results are in accordance with the results of Marshall et al. (2003) [18] as they reported that the $\mathrm{pH}$ values in ice cream are generally ranged between 6.3 and 6.5 and this approximates what we got in the present study, also are in accordance with findings of Khalil and Embaby (2012) [49] and El-Samahy et al. (2015) [50]. Moreover, the obtained results revealed that the $\mathrm{pH}$ of different ice cream samples was affected by the type of addition. The control ice cream had the highest $\mathrm{pH}$ value (6.50). On the other hand, the $\mathrm{pH}$ values of the ice cream supplemented with RDSP, decreases with increasing the concentrations of added RDSP; as the $\mathrm{pH}$ values of $\mathrm{T}_{3}, \mathrm{~T}_{4}$ and $\mathrm{T}_{5}$ treatments were $6.45,6.40$ and 6.25, respectively; these results were disagreement with findings of Younis (2012) [46]. The addition of Nescafé lead to decreasing in the $\mathrm{pH} 6.15$ compared to all other samples.

\subsection{Soluble Fiber of Ice Cream Treatments}

Soluble fiber content was explained in Table 5, an increase in total solids indicates increase in dietary fiber of the raw materials (see Table 1) and hence in the resulted ice cream. Control sample was free of fiber $(0.00 \%)$, this may attribute to the fact that no fiber in milk. Moreover, the soluble fiber content of $\mathrm{T}_{3}$ treatment is also low (1.26\%) compared to $\mathrm{T}_{1}, \mathrm{~T}_{2}, \mathrm{~T}_{4}$ and $\mathrm{T}_{5}$ treatments which were about $1.70 \%, 1.86 \%, 1.70 \%$ and $2.10 \%$, respectively. In ice cream samples made with $3 \%$ Coffee $\left(\mathrm{T}_{2}\right)$ and $4 \%$ RDSP $\left(\mathrm{T}_{4}\right)$. These results are in agreement with (Hussein and Ali, 2017 [13]). Therefore, the RDSP as by-products could be used in ice cream making, for improving its content from soluble fibers. Furthermore, Besbes et al. (2004b) [47] mentioned that the date seeds could be regarded as an excellent source of food ingredients with interesting technological functionality that could also be used in food as an important source of dietary fiber.

\subsection{Minerals Content of the Ice Cream Mixes}

Results in Table 6 show the difference in the content of minerals between ice cream treatments and control. Generally, there is a significant difference $(\mathrm{P} \leq$ 0.001 ) in the minerals content of the ice cream samples. It was noticed that the samples that contain Nescafé $\left(\mathrm{T}_{1}\right)$ is rich in $\mathrm{Mg}$ and $\mathrm{K} ; 183.020$ and 1235.520 $\mathrm{mg} / \mathrm{L}$, respectively. While, ice cream samples with added coffee are rich in $\mathrm{Fe}, \mathrm{P}$, $\mathrm{Cu}, \mathrm{Mn}$ and Ni; $16.198,5.396,1.722,1.083$ and $1.537 \mathrm{mg} / \mathrm{L}$, respectively, compared to other treatments samples. Zinc element also was high in $\mathrm{T}_{2}$ treatment that containing Coffee as it recorded $4.155 \mathrm{mg} / \mathrm{L}$, while the samples of added 
Table 6. Minerals content in the mixes of different functional ice cream with coffee-related flavor.

\begin{tabular}{|c|c|c|c|c|c|c|c|}
\hline \multirow{2}{*}{$\begin{array}{l}\text { Minerals } \\
(\mathrm{mg} / \mathrm{L})\end{array}$} & \multicolumn{7}{|c|}{ Treatments* } \\
\hline & Control & $\mathrm{T} 1$ & $\mathrm{~T} 2$ & T3 & $\mathrm{T} 4$ & T5 & SE \pm \\
\hline $\mathbf{P}$ & $858.34^{\mathrm{F}}$ & $952.78^{\mathrm{B}}$ & $954.63^{\mathrm{A}}$ & $897.02^{\mathrm{E}}$ & $910.58^{\mathrm{D}}$ & $924.14^{\mathrm{C}}$ & 0.538 \\
\hline $\mathrm{Fe}$ & $1.380^{\mathrm{D}}$ & $2.456^{\mathrm{C}}$ & $16.198^{\mathrm{A}}$ & $1.775^{\mathrm{D}}$ & $1.820^{\mathrm{D}}$ & $3.966^{\mathrm{B}}$ & 0.156 \\
\hline K & $577.030^{\mathrm{F}}$ & $1235.52^{\mathrm{A}}$ & $970.320^{\mathrm{B}}$ & $610.93^{\mathrm{E}}$ & $627.31^{\mathrm{D}}$ & $702.97^{\mathrm{C}}$ & 2.580 \\
\hline $\mathrm{Mg}$ & $121.320^{\mathrm{D}}$ & $183.020^{\mathrm{A}}$ & $155.420^{\mathrm{B}}$ & $110.74^{\mathrm{E}}$ & $111.60^{\mathrm{E}}$ & $133.87^{\mathrm{C}}$ & 0.360 \\
\hline $\mathrm{Ca}$ & $1067.880^{\mathrm{A}}$ & $967.980^{\mathrm{C}}$ & $1052.380^{\mathrm{B}}$ & $730.98^{\mathrm{F}}$ & $796.48^{\mathrm{E}}$ & $822.43^{\mathrm{D}}$ & 3.38 \\
\hline $\mathrm{Zn}$ & $2.639^{\mathrm{D}}$ & $3.718^{\mathrm{BC}}$ & $4.155^{\mathrm{B}}$ & $2.772^{\mathrm{D}}$ & $2.832^{\mathrm{CD}}$ & $5.605^{\mathrm{A}}$ & 0.29 \\
\hline Mn & $0.244^{\mathrm{E}}$ & $0.564^{\mathrm{B}}$ & $1.083^{\mathrm{A}}$ & $0.402^{\mathrm{D}}$ & $0.488^{\mathrm{C}}$ & $0.595^{\mathrm{B}}$ & 0.013 \\
\hline $\mathrm{Cu}$ & $0.593^{\mathrm{B}}$ & $0.722^{\mathrm{B}}$ & $1.722^{\mathrm{A}}$ & $0.626^{\mathrm{B}}$ & $0.698^{\mathrm{B}}$ & $0.873^{\mathrm{B}}$ & 0.097 \\
\hline $\mathrm{Ni}$ & $0.079^{\mathrm{D}}$ & $0.0217^{\mathrm{BC}}$ & $1.537^{\mathrm{A}}$ & $0.031^{\mathrm{D}}$ & $0.154^{\mathrm{C}}$ & $0.233^{\mathrm{B}}$ & 0.021 \\
\hline $\mathrm{Cd}$ & $0.029^{\mathrm{E}}$ & $0.048^{\mathrm{D}}$ & $0.082^{\mathrm{B}}$ & $0.050^{\mathrm{CD}}$ & $0.059^{\mathrm{C}}$ & $0.098^{\mathrm{A}}$ & 0.003 \\
\hline $\mathrm{Pb}$ & $0.008^{\mathrm{F}}$ & $0.11^{\mathrm{C}}$ & $0.028^{\mathrm{E}}$ & $0.060^{\mathrm{D}}$ & $0.123^{\mathrm{B}}$ & $0.147^{\mathrm{A}}$ & 0.12 \\
\hline
\end{tabular}

$\mathrm{A}, \mathrm{B}, \ldots$ and $\mathrm{F}$ : Means in the same row with different superscript letters are significantly different $(\mathrm{P} \leq$ 0.001), SE \pm : standard error. ${ }^{*}$ See Table 5).

Nescafé or date seeds powder were 3.718 and $2.772 \mathrm{mg} / \mathrm{L}$, respectively. Control samples is higher in Calcium content; $1067.88 \mathrm{mg} / \mathrm{L}$ than the other ice cream treatments followed by $\mathrm{T}_{2}$ treatment, this result was in agreement with Younis (2012) [46]. Also it is noticed an increase in the content of the minerals with increasing dates seeds powder concentration. These results are in accordance with that reported by Ali and Khamis (2004) [51] and Younis (2012) [46].

\subsection{Physical Properties of Different Functional Ice Cream Mixes and Resultant Ice Creams}

\section{Viscosity and freezing point of the ice cream mixes}

The differences in viscosity (CP) of ice cream mixes were illustrated in Figure 2. It is affected by many factors including the presence and concentration of the components (e.g., fat, polysaccharides and proteins), hydration phenomena occurring during ageing, protein aggregation, fat crystallization, fat coalescence, etc. [52]. The results indicated that the addition of RDSP at ratios of 3\%, $4 \%$ and $5 \%$ in ice cream mix increasing the viscosity values, where it was; $239.7,243.3$ and $266.00 \mathrm{CP}$, respectively compared with control (189.00 CP). These results were in agreement with finding of Khalil and Blassey (2016) [53]. While, the viscosity of Nescafé and Coffee ice cream mixes were about 166.9 and $229.8 \mathrm{CP}$, respectively.

Freezing point values of all ice cream mixes and control are summarized in Figure 3. One of the most critical parameters in ice cream production is the freezing point depression; because of its influence in the initial and gradual growths of the mean size of the formed ice crystals and also their native thermodynamic 


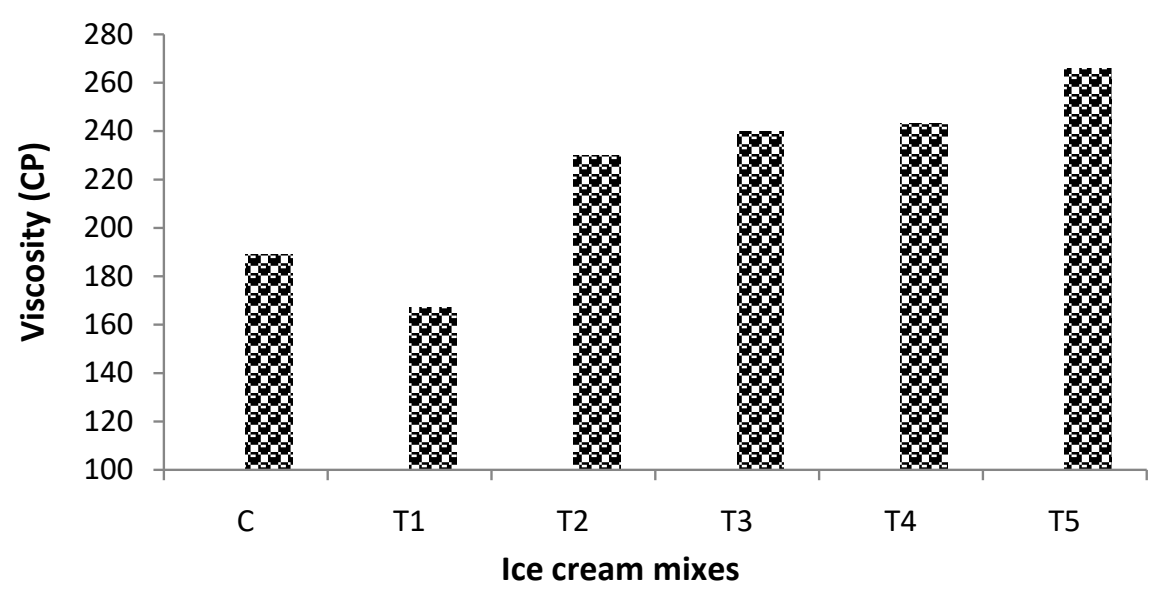

Figure 2. Effect of different coffee-related flavor additives on the viscosity of ice cream mixes.

Treatments
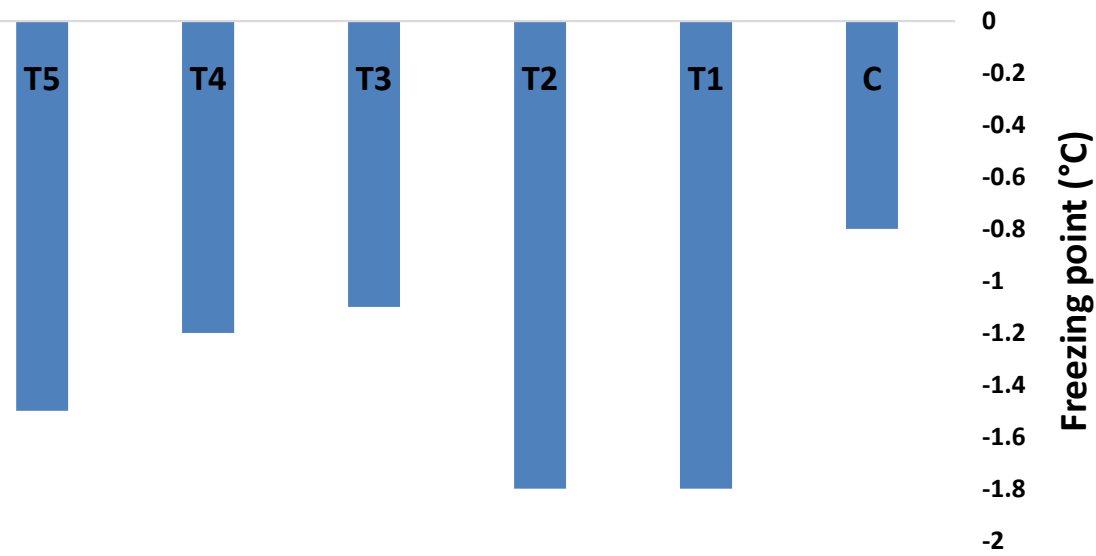

Figure 3. Effect of adding different ratios of roasted date seed powder, coffee and Nescafé on freezing point $\left({ }^{\circ} \mathrm{C}\right)$ of ice cream mixes.

instability [53]. Results showed difference in freezing point depression in $\mathrm{T}_{2}$ and $\mathrm{T}_{3}$ ice cream mixes compared to samples of $\mathrm{T}_{4}, \mathrm{~T}_{5}$ and $\mathrm{T}_{1}$ ice cream mixes, which can be attributed to the differences in solids not fat (SNF) content. Using RDSP at ratios of $3 \%, 4 \%$ and $5 \%$ in the ice cream changes the freezing point to $-1.1^{\circ} \mathrm{C}$, $-1.2^{\circ} \mathrm{C}$ and $-1.5^{\circ} \mathrm{C}$, respectively. This could be attributed to the contents of RDSP from carbohydrate and minerals. While, treatments of $\mathrm{T}_{2}$ and $\mathrm{T}_{3}$ having the same freezing point value $\left(-1.8^{\circ} \mathrm{C}\right)$. These results are compatible with Khalil and Blassey (2016) [53]. Generally, the freezing point is depressed as the soluble substances are increased or as the solutes molecular weight is decreased [54].

\subsection{Some Physical Properties of Resultant Ice Cream Mixes and Final Product}

The results illustrated in Figure 4 and Figure 5 show the differences in specific gravity and weight per gallon values between different mixes. The ice cream mixes 


\section{훙 Specific gravity of mixes $\quad$ Specific gravity of ice milk}

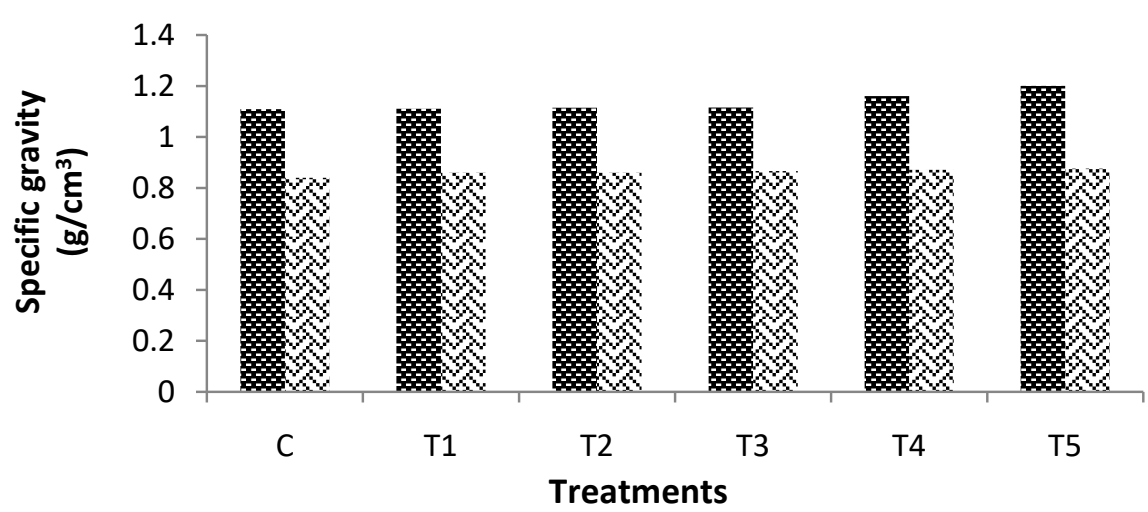

Figure 4. Specific gravity $\left(\mathrm{g} / \mathrm{cm}^{3}\right)$ values in mixes and ice cream treatments as affected by different coffee related flavor additives.

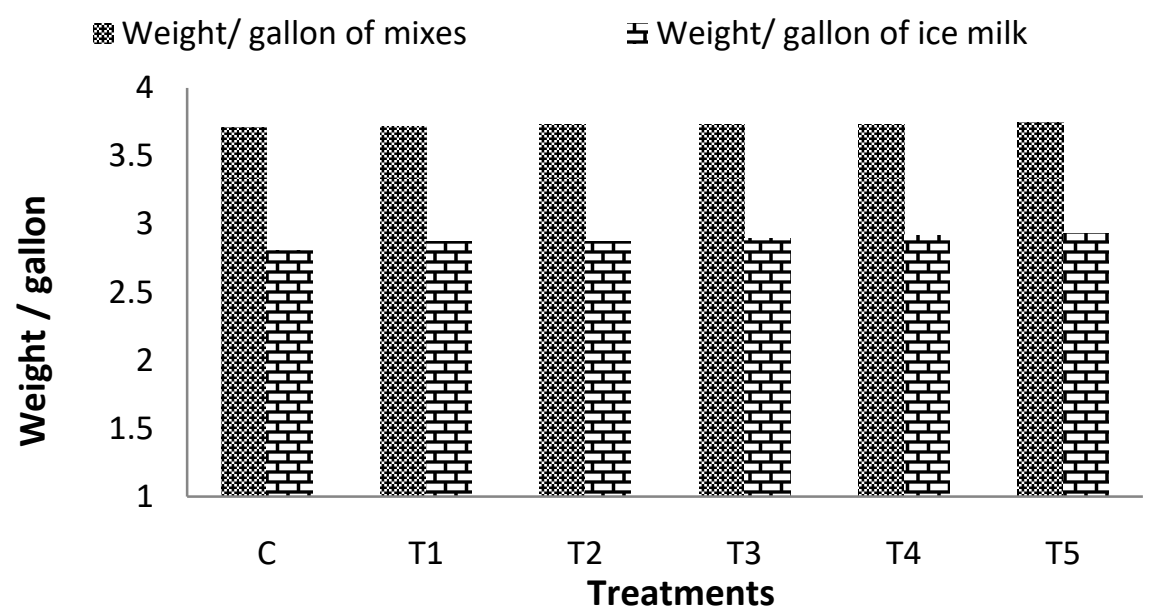

Figure 5. Weight per gallon $(\mathrm{Kg})$ values in mixes and ice cream treatments as affected by different coffee related flavor additives.

that supplemented with RDSP show significance difference $(\mathrm{P} \leq 0.001)$ in both specific gravity $\left(\mathrm{g} / \mathrm{cm}^{3}\right)$ and weight per gallon $(\mathrm{Kg})$ values comparing with control and the other mixes. The highest specific gravity value $\left(1.2 \mathrm{~g} / \mathrm{cm}^{3}\right)$ was for the ice cream mix contain $5 \%$ RDSP, while the lowest reading $\left(1.109 \mathrm{~g} / \mathrm{cm}^{3}\right)$ recorded for the ice cream control mix. The values of weight per gallon for the previous ice cream mixes were 3.746 and $3.709 \mathrm{Kg}$, respectively. Regarding these results; addition of RDSP increases both the specific gravity and weight per gallon values. These results were in agreement with Khalil and Blassey (2016) [53].

Similar results of specific gravity and weight per gallon for the final functional ice cream product are obtained (Figure 4 and Figure 5), the results revealed that specific gravity and weight per gallon values between ice cream treatments were significant $(\mathrm{P} \leq 0.001)$. The highest specific gravity value $\left(0.876 \mathrm{~g} / \mathrm{cm}^{3}\right)$ was recorded for the ice cream treatment that contains RDSP (3\%), while the lowest value $\left(0.84 \mathrm{~g} / \mathrm{cm}^{3}\right)$ recorded for the control sample. The values of weight per gallon for the previous ice cream treatments were, $2.93,2.876$ and $2.876 \mathrm{Kg}$ for $\mathrm{T}_{5}, \mathrm{~T}_{1}$, 
and $\mathrm{T}_{2}$ treatments, respectively compared with $2.81 \mathrm{Kg}$ for control. These results were in agreement with what reported by Khalil and Blassey (2016) [53].

\subsection{Overrun of the Ice Cream Treatments}

Overrun is one of the most critical parameter in ice cream production. In this study the overrun was determined in the ice cream samples and given in Figure 6 , the overrun values were ranged from $92.6 \%$ to $116.5 \%$. Increasing the concentration of RDSP in ice cream treatments; $\mathrm{T}_{3}, \mathrm{~T}_{4}$ and $\mathrm{T}_{5}$ lead to an increase for the overrun reading which were, $113.9 \%, 116.4 \%$ and $116.5 \%$, respectively compared with control (109\%). This is might be related to increasing the solids ratio, which reduces the whipping ability and therefore decreases the overrun. These results were in agreement with Khalil and Blassey (2016) [53]. While, addition of Nescafé or Coffee decreased the overrun values to $92.6 \%$ and $107.9 \%$, respectively.

\subsection{First Drop and Melting Resistance of the Ice Cream Treatments}

The first dripping (min.) of ice cream treatments are shown in Figure 7(A). The ice cream that supplemented with RDSP has first dripping of 23, 21 and $19 \mathrm{~min}$. for $T_{3}, T_{4}$ and $T_{5}$ treatments, respectively. These previous samples take longer time at the beginning of the melting than samples of control, $\mathrm{T}_{1}$ and $\mathrm{T}_{2}$ treatments, which recorded 18, 16 and 13 min., respectively.

Melting resistance of functional ice cream and control samples was illustrated in Figure 7(B), the type and levels of the added materials had a significant effect $(\mathrm{P} \leq 0.001)$ on melting resistance of the resulted ice cream. The highest melting resistance sample was recorded for $\mathrm{T}_{5}$ treatment (60.034\%) while, the lowest reading was observed in $\mathrm{T}_{2}$ treatment (38.369\%). Results also showed that as the concentration of RDSP increased, the melting resistance increased this may be due to the high overrun which mean more air incorporation and hence reduction of heat transfer, these results are disagreement with findings of Khalil and Blassey (2016) [53].

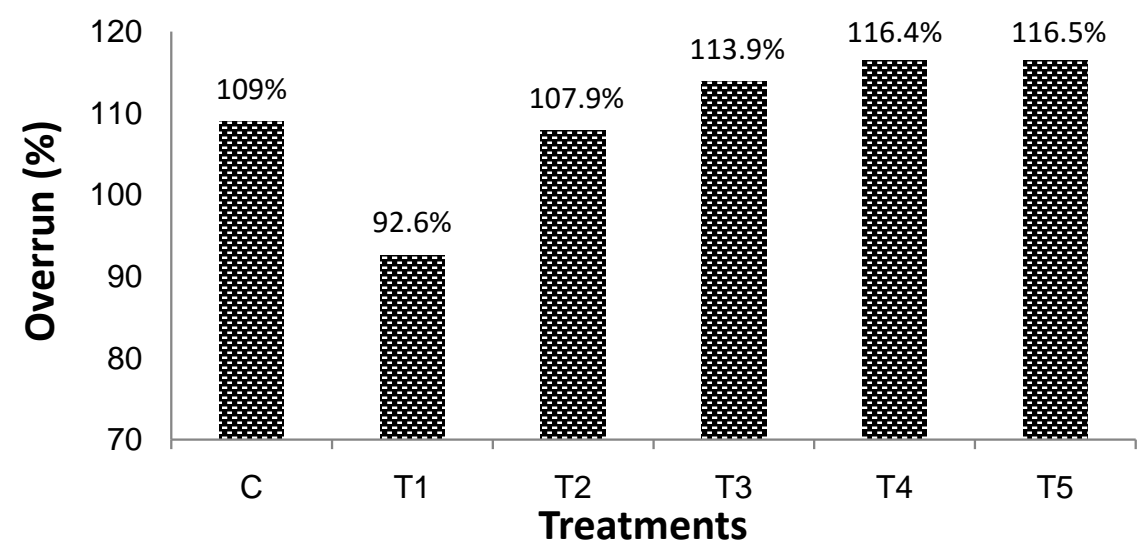

Figure 6. Overrun values of ice cream treatments as affected by adding different coffee-related flavor additives. 


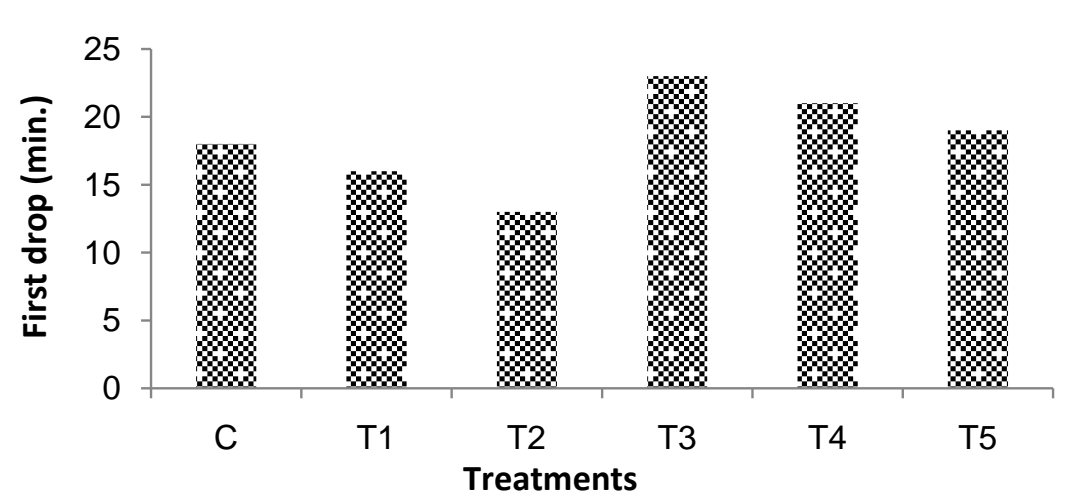

(A)

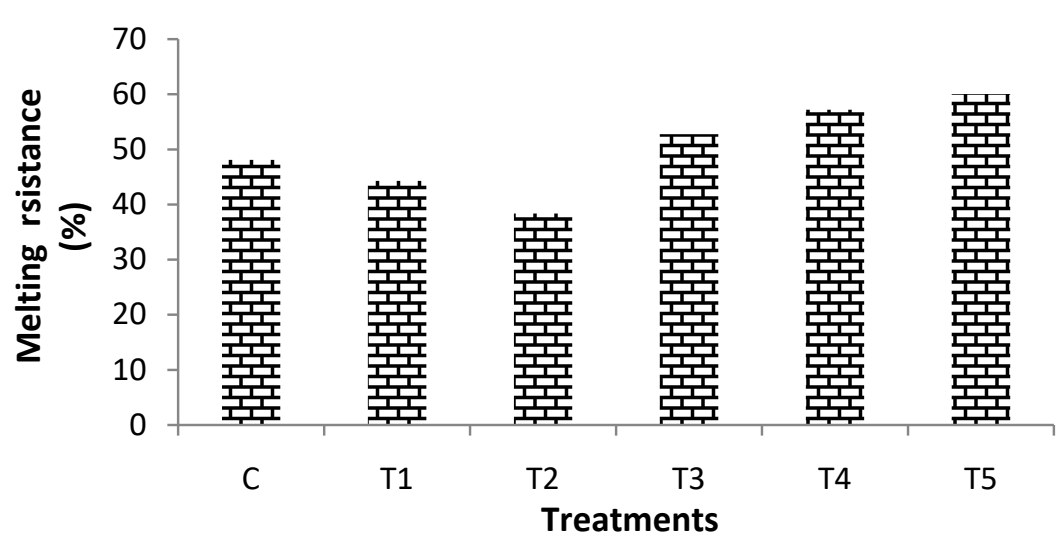

(B)

Figure 7. First drop ( $\min )$. (A) melting resistance (\%), (B) ice cream treatments as affected by adding different coffee related flavor additives (after $45 \mathrm{~min}$.).

The melting resistance of ice cream is affected by many factors, including the amount of air incorporated, the nature of the ice crystals and the network of fat globules formed during freezing [21]. Also Sakurai et al. (1996) [55] reported that ice cream with low overruns melted quickly, while, ice cream with high overruns began to melt slowly and had a good melting resistance. This slower melting rate in the ice creams with high overruns was attributed to a reduced rate of heat transfer due to a larger volume of air [55]. Ice cream with low overrun was harder than those made with high overrun and melted more rapidly [56].

\subsection{Color Measurement}

The measuring of color changing in the functional ice cream treatments compared with control is shown in Table 7. The color of ice cream shifted from white towards the red/yellow chromaticity as shown by decreasing lightness ( $\mathrm{L}^{*}$ values) in all treatments during storage period. This change in color corresponded with type of addition and the level of addition. The control sample exhibited the highest lightness; $L^{*}$ values, 89.76 and reached to 86.89 by the end of storage period. Regarding the $\mathrm{a}^{*}$ values, the control samples had an intense greenness, as indicated by a negative $\mathrm{a}^{\star}$ mean values during storage. 
Table 7. Effect of adding roasted date seed powder, coffee and nescafé on color changing of the ice cream treatments.

\begin{tabular}{|c|c|c|c|c|}
\hline Treatments ${ }^{* *}$ & Day & $L^{*}$ & $a^{*}$ & $b^{*}$ \\
\hline & 1 & $89.76^{\mathrm{A}}$ & $-3.66^{\mathrm{N}}$ & $16.14^{\mathrm{Q}}$ \\
\hline \multirow[t]{3}{*}{ Control } & 15 & $88.04^{\mathrm{A}}$ & $-4.08^{\mathrm{O}}$ & $17.92^{\mathrm{K}}$ \\
\hline & 30 & $86.89^{\mathrm{A}}$ & $-4.55^{\mathrm{P}}$ & $19.35^{\mathrm{H}}$ \\
\hline & 1 & $30.93^{\mathrm{F}}$ & $9.41^{\mathrm{H}}$ & $25.55^{\mathrm{B}}$ \\
\hline \multirow[t]{3}{*}{$\mathrm{T}_{1}$} & 15 & $30.09^{\mathrm{F}}$ & $9.33^{\mathrm{I}}$ & $23.92^{\mathrm{C}}$ \\
\hline & 30 & $31.88^{\mathrm{F}}$ & $8.32^{\mathrm{K}}$ & $18.77^{\mathrm{J}}$ \\
\hline & 1 & $44.57^{\mathrm{BCD}}$ & $8.66^{\top}$ & $25.92^{\mathrm{A}}$ \\
\hline \multirow[t]{3}{*}{$\mathrm{T}_{2}$} & 15 & $34.91^{\mathrm{EF}}$ & $7.72^{\mathrm{L}}$ & $20.92^{\mathrm{E}}$ \\
\hline & 30 & $34.1^{\mathrm{EF}}$ & $7.31^{\mathrm{M}}$ & $20.06^{\mathrm{F}}$ \\
\hline & 1 & $48.99^{\mathrm{BC}}$ & $11.66^{\mathrm{G}}$ & $17.83^{\mathrm{L}}$ \\
\hline \multirow[t]{3}{*}{$\mathrm{T}_{3}$} & 15 & $47.17^{\mathrm{BC}}$ & $11.72^{\mathrm{F}}$ & $17.47^{\mathrm{M}}$ \\
\hline & 30 & $46.62^{\mathrm{BC}}$ & $11.72^{\mathrm{F}}$ & $16.82^{\mathrm{O}}$ \\
\hline & 1 & $50.05^{\mathrm{B}}$ & $12.73^{\mathrm{C}}$ & $19.51^{\mathrm{G}}$ \\
\hline \multirow[t]{3}{*}{$\mathrm{T}_{4}$} & 15 & $46.12^{\mathrm{BCD}}$ & $12.29^{\mathrm{D}}$ & $17.74^{\mathrm{L}}$ \\
\hline & 30 & $44.84^{\mathrm{BCD}}$ & $11.85^{\mathrm{E}}$ & $17.02^{\mathrm{N}}$ \\
\hline & 1 & $43.64^{\mathrm{BCD}}$ & $13.92^{\mathrm{A}}$ & $19.21^{\mathrm{I}}$ \\
\hline \multirow[t]{2}{*}{$\mathrm{T}_{5}$} & 15 & $42.56^{\mathrm{CD}}$ & $12.89^{\mathrm{B}}$ & $16.77^{\mathrm{O}}$ \\
\hline & 30 & $39.3^{\mathrm{DE}}$ & $12.7^{\mathrm{C}}$ & $16.51^{\mathrm{P}}$ \\
\hline SE \pm & & 1.48 & 0.237 & 0.638 \\
\hline
\end{tabular}

$L^{*}$ : denotes lightness from black $(0)$ to white $(100), a^{*}$ : redness $(+)$ to greenness $(-), b^{*}$ : yellowness $(+)$ to blueness $(-)$. A, B, ... and Q: means in the same column with different superscript letters are significantly different $(\mathrm{P} \leq 0.001), \mathrm{SE} \pm$ : standard error, ${ }^{* *}$ See Table 5.

It is worth mention that comparing to control; the samples of all other ice cream treatments exhibited an increase in redness (+ve $\mathrm{a}^{\star}$ values) especially the samples made with date seed powder, followed with samples of ice cream made with coffee. The intense redness of samples supplemented with RDSP corresponded with the increase of the added concentrations. In terms of $b^{*}$ values, the control showed less yellowness (16.14) than other flavored samples.

\subsection{Organoleptic Properties}

The Effect of adding different RDSP, Coffee or Nescafé on sensory properties of functional ice cream treatments and control are presented in Table 8. In general, addition of different levels of RDSP had a high significant $(P \leq 0.001)$ effect on all sensory parameters of the resultant ice cream samples compared with both Nescafé and Coffee ice cream. Regarding, Flavor and Body \& texture points for ice cream samples with $3 \%$ added RDSP were 47.78 and 28.03, respectively, which were higher than samples with added Nescafé $\left(T_{1}\right)$ or coffee $\left(T_{2}\right)$. The evaluation of melting rate was increased with increasing the added level of RDSP; however, the Nescafé sample was the least melting rate (8.08). 
Table 8. Sensory evaluation of the functional new natural coffee-like flavor ice cream.

\begin{tabular}{cccccc}
\hline & \multicolumn{5}{c}{ Parameters } \\
\cline { 2 - 6 } Treatments $^{*}$ & $\begin{array}{c}\text { Flavor } \\
(50)\end{array}$ & $\begin{array}{c}\text { Body \& Texture } \\
(30)\end{array}$ & $\begin{array}{c}\text { Melting quality } \\
(10)\end{array}$ & $\begin{array}{c}\text { Color } \\
(10)\end{array}$ & $\begin{array}{c}\text { Total score } \\
(100)\end{array}$ \\
\hline Control & $46.36^{\mathrm{D}}$ & $27.79^{\mathrm{B}}$ & $8.93^{\mathrm{A}}$ & $8.43^{\mathrm{D}}$ & $91.51^{\mathrm{C}}$ \\
$\mathrm{T}_{1}$ & $42.57^{\mathrm{F}}$ & $26.29^{\mathrm{F}}$ & $8.08^{\mathrm{D}}$ & $7.50^{\mathrm{F}}$ & $84.44^{\mathrm{F}}$ \\
$\mathrm{T}_{2}$ & $43.17^{\mathrm{E}}$ & $26.71^{\mathrm{E}}$ & $8.86^{\mathrm{B}}$ & $7.93^{\mathrm{E}}$ & $86.67^{\mathrm{E}}$ \\
$\mathrm{T}_{3}$ & $47.78^{\mathrm{A}}$ & $28.03^{\mathrm{A}}$ & $8.85^{\mathrm{B}}$ & $8.71^{\mathrm{C}}$ & $93.37^{\mathrm{A}}$ \\
$\mathrm{T}_{4}$ & $47.10^{\mathrm{B}}$ & $27.36^{\mathrm{C}}$ & $8.86^{\mathrm{B}}$ & $8.91^{\mathrm{B}}$ & $92.23^{\mathrm{B}}$ \\
$\mathrm{T}_{5}$ & $46.00^{\mathrm{C}}$ & $27.30^{\mathrm{D}}$ & $8.21^{\mathrm{C}}$ & $9.29^{\mathrm{A}}$ & $90.80^{\mathrm{D}}$ \\
$\mathrm{SE}$ & 0.019 & 0.014 & 0.005 & 0.004 & 0.005 \\
\hline
\end{tabular}

$\mathrm{A}, \mathrm{B}, \ldots$ and $\mathrm{F}$ : means in the same column with different superscript letter are significantly different $(\mathrm{P}<$ 0.001). SE \pm : standard error. ${ }^{*}$ See Table 1.

According to Schmidt and Smith (1992) [57], the improvement in melting quality and Body \& texture could be attributed to the increase in viscosity and/or overrun, which inhibits the development of ice crystals in the frozen ice cream. The RDSP ice cream treatments; $\mathrm{T}_{3}, \mathrm{~T}_{4}$ and $\mathrm{T}_{5}$ are higher in color points as it recorded $8.71,8.91$ and 9.29 , respectively than the other ice cream treatments and control. These results were in agreement with what reported by Khalil and Blassey (2016) [53]. Generally, all samples of the different functional ice cream treatments were appreciative from the panelist and they admired precisely the samples that supplemented with RDSP.

\section{Conclusion}

The increasing demands by consumers for functional foods that provided health benefits should be considered. So an extensive work is given on recycling by-products from food processing industries into high quality products. Date seed is one of the common wastes of date industries. It can be used as a functional food ingredient in dairy industries because they are a good source of dietary fiber, phenolic compounds and antioxidant activity. Furthermore, it contains many food ingredients such as protein and minerals. In this study and from previous results it is recommended using RDSP as source of minerals and health-promoting in the manufacture of ice cream, as it contains bioactive compounds and also gives the ice cream desirable color and coffee-like flavor, but free of caffeine.

\section{Funding}

This research work has no financial support, authorship, and/or publication of this article.

\section{Conflicts of Interest}

The authors declare no conflicts of interest regarding the publication of this paper. 


\section{References}

[1] Karaman, S. and Kayacier, A. (2012) Rheology of Ice Cream Mix Flavored with Black Tea or Herbal Teas and Effect of Flavoring on the Sensory Properties of Ice Cream. Food and Bioprocess Technology, 5, 3159-3169. https://doi.org/10.1007/s11947-011-0713-5

[2] Bearth, A., Cousin, M.E. and Siegrist, M. (2014) The Consumer's Perception of Artificial Food Additives: Influences on Acceptance, Risk and Benefit Perceptions. Food Quality and Preference, 38, 14-23. https://doi.org/10.1016/j.foodqual.2014.05.008

[3] Garcia, C., Bautista, L., Rendueles, M. and Diaz, M. (2019) A New Synbiotic Dairy Food Containing Lactobionic Acid and Lactobacillus casei. International Journal of Dairy Technology, 72, 47-56. https://doi.org/10.1111/1471-0307.12558

[4] International Coffee Organization (ICO) Statistics. Breakdown of Exports of Green Arabica and Green Robusta of Countries Exporting Significant Volumes of Both Types of Coffee June 2009. https://www.ico.org

[5] Bae, J.-H., Park, J.-H., Im, S.-S. and Song, D.-K. (2014) Coffee and Health. Integrative Medicine Research, 3, 189-191. https://doi.org/10.1016/j.imr.2014.08.002

[6] Tenore, G.C., Daglia, M., Orlando, V., Urso, E.D., Saadat, S.H., Novellino, E., Nabovi, S.F. and Nabavi, S.M. (2015) Coffee and Depression: A Short Review of Literature. Current Pharmaceutical Design, 21, 5034-5040. https://doi.org/10.2174/1381612821666150825145112

[7] Ramalakshmi, K. and Rao, L.J.M. (2008) A Perception on Health Benefits of Coffee. Critical Reviews in Food Science and Nutrition, 48, 464-486. https://doi.org/10.1080/10408390701522445

[8] Hashim, I.B., Khalil, A.H. and Afifi, H.S. (2009) Quality Characteristics and Consumer Acceptance of Yoghurt Fortified with Date Fiber. Journal of Dairy Science, 92, 5403-5407. https://doi.org/10.3168/jds.2009-2234

[9] Parvin, S., Easmin, D., Sheikh, A., Biswas, M., Sharma, S.C.D., Jahan, M.G.S., Islam, M.d.A., Roy, N. and Shovon, M.S. (2015) Nutritional Analysis of Date Fruits (Phoenix dactylifera L.) in Perspective of Bangladesh. American Journal of Life Sciences, 3, 274-278. https://doi.org/10.11648/j.ajls.20150304.14

[10] Nehdi, I., Omri, S., Khalil, M. and Al-Resayes, S. (2010) Characteristics and Chemical Composition of Date Palm (Phoenix canariensis) Seeds and Seed Oil. Industrial Crops and Products, 32, 360-365. https://doi.org/10.1016/j.indcrop.2010.05.016

[11] Ardekani, M.R.S., Khanavi, M., Hajimahmoodi, M., Jahangiri, M. and Hadjiakhoondi, A. (2010) Comparison of Antioxidant Activity and Total Phenol Contents of Some Date Seed Varieties from Iran. Iranian Journal of Pharmaceutical Research: IJPR, 9, 141.

[12] Al-Farsi, M.C., Al-Abid, A.M., Al-Shoaily, K., Al-Amry, M. and Al-Rawahy, F. (2007) Compositional and Functional Characteristics of Dates, Syrups, and Their By-Products. Food Chemistry, 104, 943-947. https://doi.org/10.1016/j.foodchem.2006.12.051

[13] Hussein, A.M.S. and Ali, H.S. (2017) Chemical and Technological Properties of Improved Snacks from Oat and Date Seeds Composite Flour. American Journal of Food Technology, 12, 201-208. https://doi.org/10.3923/ajft.2017.201.208

[14] Shayeb, M.A., Alharbi, T. and Baloch, M.A. (2017) Transfer Factors for Natural Radioactivity into Date Palm Pits. Journal of Environmental Radioactivity, 167, 75-79. https://doi.org/10.1016/j.jenvrad.2016.11.014

[15] Al-Degs, Y.S., El-Sheikh, A.H. and Jaber, S.T. (2013) Application of Heated Date Seeds as a Novel Extractant for Diuron from Water. Arabian Journal of Chemistry, 


\section{6, 121-129. https://doi.org/10.1016/j.arabjc.2011.07.015}

[16] Shin, Y., Liu, R.H., Nock, J.F., Holliday, D. and Watkins, C.B. (2007) Temperature and Relativity Humidity Effects on Quality, Total Ascorbic Acid, Phenolics and Flavonoid Concentrations, and Antioxidant Activity of Strawberry. Postharvest Biology and Technology, 45, 349-357. https://doi.org/10.1016/j.postharvbio.2007.03.007

[17] Pacôme, O.A., Bernard, D., Sékou, D., Allico, D., David, J., Monqomaké, K. and Hilaire, K. (2014) Phytochemicals and Antioxidant Activity of Roselle (Hibiscus Sabdariffa L.) Petal Extracts. Research Journal of Pharmaceutical, Biological and Chemical Sciences, 5, 1453-1465

[18] Marshall, R.T., Goff, H.D. and Hartel, R.W. (2003) Ice Cream. 6th Edition, Kluwer Academic/Plenum Publishers, New York, 11-54. https://doi.org/10.1007/978-1-4615-0163-3

[19] Egyptian Standards (2005) Milk and Water Ice (Ices Cream) ES: 1185, Part: 1, Milk Ice, Part: 2, Water Ices. Ministry of Industry and Technology Development, Egyptian Organization for Standardization and Quality Control.

[20] Toledo, T.T. (1980) Impact of Taro Corms on Functional Low Fat Ice Cream in "Fundamental of Food Process Engineering". AVI Pub.

[21] Moeenfard, M. and Teharni, M.M. (2008) Effect of Some Stabilizers on the Physicochemical and Sensory Properties of Ice Cream Type Frozen Yogurt. American-Eurasian Journal of Agricultural \& Environmental Sciences, 4, 584-589.

[22] Winton, A.L. (1958) Analysis of Foods. $3^{\text {rd }}$ Printing. John Wiley and Sons Inc., New York.

[23] Arbuckle, W.S. (1986) Ice Cream. $4^{\text {th }}$ Edition, AVI Publishing Co. Inc., Westport.

[24] FAO (1977) Food and Agriculture Organization of the United Nations. Laboratory Manual Food and Agriculture.

[25] Park, S.H., Jo, Y.J., Chun, J.Y., Hong, G.P., Davaatseren, M. and Choi, M.J. (2015) Effect of Frozen Storage Temperature on the Quality of Premium Ice Cream. Korean Journal for Food Science of Animal Resources, 35, 793-799. https://doi.org/10.5851/kosfa.2015.35.6.793

[26] AOAC Association of Official Analytical Chemists (2012) Official Methods of Analysis. $18^{\text {th }}$ Edition, AOAC International, Gaithersburg.

[27] APHA American Public Health Association (2005) Standard Methods for the Examination of Water and Wastewater. 3120 "B" Inductively Coupled Plasma (ICP) Method, Washington DC, 3-44.

[28] Rashida, R.T.A. and Joy, P.P. (2014) Proximate Analysis of Food Samples. In: A Food Technology Lab Manual, Kerala Agricultural University Pineapple Research Station, Odakkali, 15-19.

[29] Magdoub, M.N.I., Hammad, Y.A. and Yassen, M.M. (1989) Effect of Vegetable Oils on Plain Ice Cream Properties. Egyptian Journal of Food Science, 19, 9-15.

[30] SPSS (2008) Statistical Package for Social Sciences. Version 17.0.0, SPSS Corporation.

[31] Duncan, D. (1955) Multiple Range and Multiple F Test. Biometrics, 11, 1-45. https://doi.org/10.2307/3001478

[32] Oestreich-Janzen, S. (2010) Chemistry of Coffee. CAFEA GmbH, Elsevier Ltd., Hamburg, Germany, Vol. 3, 1085-1096. https://doi.org/10.1016/B978-008045382-8.00708-5

[33] Farah, A. (2012) Coffee: Emerging Health Effects and Disease Prevention. John Wiley \& Sons, Blackwell Publishing Ltd. 
[34] Yousuf, R.G. and Winterburn, J.B. (2016) Date Seed Characterizations, Substrate Extraction and Process Modelling for the Production of Polyhydroxybutyrate by Cupriavidus necator. Bioresource Technology, 222, 242-251.

https://doi.org/10.1016/j.biortech.2016.09.107

[35] Han, X., Lee, F.L., Zhang, L. and Guo, M.R. (2012) Chemical Composition of Water Buffalo Milk and Its Low-Fat Symbiotic Yogurt Development. Functional Foods in Health and Disease, 2, 86-106. https://doi.org/10.31989/ffhd.v2i4.96

[36] El-Salam, M.H.A. and El-Shibiny, S. (2011) A Comprehensive Review on the Composition and Properties of Buffalo Milk. Dairy Science \& Technology, 91, 663-699.

https://doi.org/10.1007/s13594-011-0029-2

[37] Shi, L.-E., Zheng, W., Aleid, S.M. and Tang, Z.-X. (2014) Date Pits: Chemical Composition, Nutritional and Medicinal Values, Utilization. Crop Science, 54, 1322-1330. https://doi.org/10.2135/cropsci2013.05.0296

[38] Janda, K., Jakubczyk, K., Baranowska-Bosiacka, I., Kapczuk, P., Kochman, J., RebaczMaron, E. and Gutowska, I. (2020) Mineral Composition and Antioxidant Potential of Coffee Beverages Depending on the Brewing Method. Foods, 9, 121-137. https://doi.org/10.3390/foods9020121

[39] Albahari, P., Jug, M., Radić, K., Jurmanović, S., Brnčić, M., Brnčić, S.R. and Čepo, D.V. (2018) Characterization of Olive Pomace Extract Obtained by Cyclodextrin-Enhanced Pulsed Ultrasound Assisted Extraction. LWT_Food Science and Technology, 92, 22-31. https://doi.org/10.1016/j.lwt.2018.02.011

[40] Besbes, S., Blecker, C., Deroanne, C., Lognay, G., Drira, N. and Attia, H. (2004) Quality Characteristics and Oxidative Stability of Date Seed Oil during Storage. Food Science and Technology International, 10, 333-338. https://doi.org/10.1177/1082013204047777

[41] Amarowicz, R. and Troszyǹska, A. (2003) Antioxidant Activity of Extract of Pea and Its Fractions of Low Molecular Phenolics and Tannins. Polish Journal of Food and Nutrition Sciences, 12, 10-15.

[42] Abdullah, M., Saleem-ut-Rehman, Z.H., Saeed, H.M., Kousar, S. and Shahid, M. (2003) Effect of Skim Milk in Soymilk Blend on the Quality of Ice Cream. Pakistan Journal of Nutrition, 2, 305-311. https://doi.org/10.3923/pjn.2003.305.311

[43] Ayar, A., Ramaz, H.S., Ozturk, S. and Yilmaz, S.O. (2018) Probiotic Properties of Ice Creams Produced with Dietary Fibers from By-Products of the Food Industry. International Journal of Dairy Technology, 71, 174-182. https://doi.org/10.1111/1471-0307.12387

[44] Hashmi, S.I., Kadam, S.S. and Kale, R.V. (2011) Studies on Effect of Different Varieties of Date Palm Paste Incorporation on Quality Characteristics of Yoghurt. Electronic Journal of Environmental, Agricultural and Food Chemistry, 10, 2371-2381.

[45] El-Shobery, M.A., Mansour, A.I.A. and Zaki, K.G. (2012) Studies on Using of Date Syrup in Yoghurt Making. Minia Journal of Agricultural Research and Development, 32, 177-194.

[46] Younis, K.H.S. (2012) Characteristics of Some Functional Foods. PhD, The Faculty of Agriculture, Assiut University, Assiut.

[47] Besbes, S., Blecker, C., Deroanne, C., Drira, N. and Attia, H. (2004) Date Seeds: Chemical Composition and Characteristic Profiles of the Lipid Fraction. Food Chemistry, 84, 577-584. https://doi.org/10.1016/S0308-8146(03)00281-4

[48] Adeosun, A.M., Oni, S.O., Ighodaro, O.M., Durosinlorun, O.H. and Oyedele, O.M. (2016) Phytochemical, Minerals and Free Radical Scavenging Profiles of Phoenix dactilyfera L. Seed Extract. Journal of Taibah University Medical Sciences, 11, 1-6. https://doi.org/10.1016/j.jtumed.2015.11.006 
[49] Khalil, R.A.M. and Embaby, H.E. (2012) The Use Jambul Fruit (Syzygium cumiri) as a Source of Natural Antioxidant in Functional Low Fat Ice Cream Making. Egyptian Journal of Dairy Science, 40, 75-84.

[50] El-Samahy, S.K., Gaballah, A.A., Embaby, G.E., Hamed, Y.S. and Khalil, R.A.M. (2015) A Novel Low Fat Ice Cream Based on the Use of Preparation of Cactus Pear (Opuntia dillenii) Pulp. Egyptian Journal of Dairy Science, 43, 91-104.

[51] Ali, M.A.Y. and Khamis, A.S.H. (2004) Mineral Ion Content of the Seeds of Six Cultivars of Bahraini Date Palm (Phoenix dactylfera). Journal of Agricultural and Food Chemistry, 52, 6522-6525. https://doi.org/10.1021/jf030518x

[52] Nor Hayati, L., Che Man, Y.B., Tan, C.P. and Aini, I.N. (2007) Stability and Rheology of Concentrated O/W Emulsions Based Soybean/Palm Kernel Olein Blends. Food Research International, 40, 1041-1051. https://doi.org/10.1016/j.foodres.2007.05.008

[53] Khalil, R.A.M. and Blassey, K.I. (2016) Novel Functional Low Fat Ice Cream Flavors with Roasted Date Seed. Egyptian Journal of Dairy Science, 44, 137-149.

[54] Hartel, R.W. (2001) Crystallization in Foods. Aspen Publishers Inc., Gaithersburg.

[55] Sakurai, K., Kokub, S., Hakamata, K., Tomita, M. and Yoshida, S. (1996) Effect of Production Conditions on Ice Cream Melting Resistance and Hardness. Milchwissenschaft, 51, 451-454.

[56] Rosalina, P., Sofian, H. and Richard, J.H. (2004) Effects of Overrun on Structural and Physical Characteristics of Ice Cream. International Dairy Journal, 14, 255-262. https://doi.org/10.1016/j.idairyj.2003.08.005

[57] Schmidt, K.A. and Smith, D.E. (1992) Rheological Properties of Gum and Milk Protein Interactions. Journal of Dairy Science, 75, 36-42. https://doi.org/10.3168/jds.S0022-0302(92)77735-2 